\title{
A Foucauldian Discourse ANALYSIS ON NEWS REPORTS ADDRESSING High School Student EnRolment Zoning Policy
}

\author{
Arima Renny Dayu Putri ${ }^{1)}$, Markus Budiraharjo ${ }^{2)}$ \\ ${ }^{1)}$ Universitas Sanata Dharma, Yogyakarta, Indonesia \\ E-mail: rimarenny@gmail.com \\ 2) Universitas Sanata Dharma, Yogyakarta, Indonesia \\ E-mail:markbudi@usd.ac.id
}

\begin{abstract}
Empirical studies drawn from a Foucauldian discourse analysis suggest the complexity of policy implementations. Policy construction and implementation involve a set of different stakeholders, causing many competing agendas from different bodies to interfere with the processes and making policy outcomes highly unpredictable. This study was set to investigate how high school student enrolment zoning policy in Indonesia was represented in major online daily journals, specifically during the two months of June and July 2019. The latest enrolment zoning policy has been considered to be too disruptive among both parents and schools. Utilizing a discourse analysis, this paper attempted to reveal what issues were addressed and what agendas or powers were contested. In this discourse analysis, it is found that the three online journals as the resources of the study were not strong enough in presenting the news. All of them have not discussed the student's aspect as the implementer of the zoning policy.
\end{abstract}

Keywords: Student Enrolment Zoning Policy; Discourse Analysis; Foucauldian Perspective

\section{INTRODUCTION}

Starting in 2018, students' enrolment zoning policy has become a major policy framework that brings much controversy. It is through this policy that public schools are mandated to prioritize the enrolment of students living nearby, no matter what they are. It means that public schools can no longer discriminate against those having poor academic performance. Issued by Muhadjir Effendy, the Indonesian Minister of Education and Culture (2014-2019), it clearly states the mandate:

The government mandates all public schools, namely elementary schools, junior high, and senior high schools to prioritize their educational services to their neighbouring areas (Education and Culture Ministry, 2018).

This policy has become a mandatory order for all public grade schools to follow. It is through such a policy that all public primary schools, junior high schools, and senior high schools cannot reject students with poor academic performance if they live within the zoning area. It is worth noting that this policy does not apply to private schools and public vocational schools.
As stated in the regulation, the implementation of the student enrolment zoning policy was based on four considerations. First, it is intended to minimize traffic jams during rush hours. Second, since schools are considered to be community-based, the policy is believed to enhance the integration of school and community. Third, this new policy is set to create a less homogenous community in the school. It is believed that making the class more heterogenous will create a better quality of teaching and learning. Last, a huge demographic shift, in which heterogeneity is met, is seen as a laboratory for unity in diversity.

Through this mandatory policy, schools have to accept all their students who live nearby the schools. Zoning policy in education has been implemented in some countries. McCulloch (1991) studied the zoning policy in New Zealand. He found that there was a significant change in the character and function of secondary school zoning. The previous objective of school zoning had changed from one of balancing out the needs of different schools to one of emphasizing the alleged rights of parents. The school zoning system intervenes a strong role for "freedom" and a weak role for "equity" that endanger some schools in a disadvantaged area. 
Zoning policy for student enrolment has been in place for almost two centuries. Mann (1868), one of the most prominent founders in the educational system in the US in the $19^{\text {th }}$ century, established a system of zoning enrolment. Since 1855, public schools have been financed by taxpayers in certain districts. Affluent communities will certainly gather more taxes, which will provide more facilities and better pay for teachers. In short, after almost two centuries in place, the zoning policy had created segregations among communities and races. Affluent communities of White European origins stay in high-end districts. Communities that house African-American families and South-American origins are more likely to be lower in terms of economics, making schools in those districts suffer from shortages and facilities.

In Indonesia, the student enrolment zoning policy, which was formally initiated in 2018, has inevitably brought some controversies. It has been considered to be too disruptive among both parents and schools. This policy showed a very significant result in education in Indonesia because it has involved many education stakeholders, government and its policy, and stakeholders, teachers, students, and students' parents, as reported in some newspapers. A case in point, a news report published in JawaPos.com (July 5 $5^{\text {th }}, 2019$ ) informed that there were some students and students' parents who conducted a demonstration to refuse the implementation of students' enrolment zoning policy.

The reason for conducting the demonstration was a point of view that zoning policy has not been suitable to be implemented in North Kalimantan. Furthermore, Ubaid Matraji from "Koalisi Masyarakat Sipil Peduli Pendidikan" mentioned on JawaPos.com on July $15^{\text {th }}, 2019$ that zoning policy was not suitable for every part of Indonesia. In this case, Ubaid argued that students' enrolment zoning policy should not be implemented in all areas of Indonesia because some areas have different qualities of schools.

This study attempts to reveal how three newspapers portrayed student enrolment zoning policy during its heated days using discourse analysis (June-July 2019). Sharp and Richardson (2001) discussed planning and environmental policy research which applied discourse analysis to combine text and systems of thought and action. They explored a Foucauldian approach that focused on the policy processes and practices associated with specific difficult planning issues. The discussion has suggested that a Foucauldian approach was in common with much research in planning and environmental policy. This relates to the complexity of the subject matter and the limited timescales under which most research was conducted.

As quoted by Hewitt (2009) from Foucault's ideas, there are four features of public policy as follows. First, public policy is an act of government to exercise its power to improve people's lives. Student enrolment zoning policy was taken as a remedy to persistent problems such as fair access to public schools, traffic jams during rush hours, and disparities across public schools. Second, public policy is concerned with the government's legitimacy as a governing body to maintain people's welfare. In Indonesia, students' enrolment zoning policy was declared by the Indonesian Minister of Education (ECM, 2018) through formal government regulation. Third, public policy can be defined as a process that is dynamic, continuous, and highly complex. It involves many elements of society. Policy decisions can invite the pros and cons and have unpredictable results. Students' enrolment zoning policy is dynamic because the government is accepting evaluation from the implementation and on the process to revise the rules. Student enrolment zoning policy involves government and society especially students and students' parents. In this case, it can be defined as a complex policy because the views of society are different from government goals and objectives in designing a zoning policy. Fourth, actions of the state are implemented through increasingly complex sets of institutions. What is decided by the central government in Jakarta will be implemented through governing bodies at provincial levels, district levels, and school levels. Just like in the student enrolment zoning policy, there are plural views even across governing bodies, making the policy implementation a highly dynamic and complex enterprise. Empirical studies drawn from critical discourse analysis on political news reports suggest that language choices utilized in the news reports are not neutral (Zhang, 2014; Hart, 2015).

To clarify the objectives of the government in setting up the students' enrolment zoning policy and the social reaction through the media, it was compulsory to conduct a discourse analysis that focuses on the implementation of school zoning policy in Indonesia. This study was set to investigate how high school student enrolment zoning policy in Indonesia was represented in major online daily journals, specifically during the two months of June and July 2019. Utilizing a discourse analysis reflected on the Foucauldian perspective, this paper attempted to reveal two research questions as follows:

1. What issues were addressed through the news reports?

2. What agendas or power were contested in the students' enrollment zoning policy?

\section{METHODOLOGY}

In this study, the researchers used a discourse analysis that focused on Foucauldian perspectives about public policymaking and implementation. As confirmed by Cheek (2004), discourse analysis is a qualitative research approach that offers the potential to challenge researchers' thinking about aspects of reality. Besides, Hewitt (2009) states that researchers will develop new insight by examining communication through discourse analysis. Student enrolment zoning policy is the aspect of reality that is associated with many elements between the state and the society. Moreover, Hewitt (2009) stated that discourse analysis is a study involving communication to gain new knowledge. Discourse analysis is a new approach to study policy because it analyses the changes in policy which has a relationship with the changes in society. The result of discourse analysis can broadly develop new insights (Sharp \& Richardson, 2001). This paper discussed the 
communication between the government in designing the school zoning policy and the society involved in the implementation of zoning policy presented in news reports. The researchers explored new knowledge about the issues addressed through the news reports and the agendas or power which were contested.

The data collection and analysis drew much from a French post-structuralist Michel Foucault, who gains popularity for his ideas on the power contestation between different agents in public policies. The researchers focused on the data gathered from three online newspapers, one was more localized by nature (i.e. KRJOGJA.com), and two were at the national levels (Kompas.com and JawaPos.com). This study focused on the Senior High Schools' issues in following the student enrolment zoning policy. Extant research in the area suggests that critical discourse analysis has largely been utilized to unmask the ideologies discriminating the oppressed groups (Ramanathan \& Hoon, 2015).

Central to Foucauldian discourse analysis is the identification of news reports sources, actors involved, and ideas being contested. The data analysis included multiple readings of the data to create thematic units drawn from the empirical data gathered.

\section{RESULTS AND DISCUSSION}

\section{A. Results}

In total, there are fourteen news reports gathered from those three major online newspapers. The data showed three major categories of reports, namely society complaints, perceived impacts, and government responses. The researchers summarized the news in Table I.

The society's complaints on the students' enrolment zoning policy implementation were presented by KRJOGJA.com and JawaPos.com daily online newspapers. Meanwhile, KOMPAS daily online newspaper did not present any news on such society complaints.

First, JawaPos.com on July 5, 2019, reported news about a demonstration done by the people of North Kalimantan because there were 500 children from the border area who did not get a school. In this case, the community considered that the students' enrolment zoning policy was not feasible to be applied because it has not accommodated the educational needs of all Indonesian students. JawaPos.com added news about society complaint on July 15, 2019, which was raised by Mr. Ubaid, a member of KMSPP, "Koalisi Masyarakat Sipil Peduli Pendidikan". He said that the zoning policy was not feasible in all regions of Indonesia due to school quality gaps. On the same date, KRJOGJA.com also covered news by FORMAYO, Mr. Darma Setiawan, the Deputy of Yogyakarta Province House of Representative. He argued that the implementation of the zoning policy should not lower the standard of superior schools, and the zoning policy should benefit both parties, students, and the government to improve the quality of education in Indonesia. Mr. Dharma added that the zoning policy narrowed the opportunities for students outside
Yogyakarta who wanted to improve their education in Yogyakarta as one of the cities of education in Indonesia. Another news on the same date, KRJOGJA.com reported news by the Deputy of Commission $\mathrm{X}$ of the Indonesian House of Representative, Mr. Ir HAR Sutan Adil Hendra, MM. He asserted that this zoning policy was detrimental to students who want to continue their study at a particular school. The latest news about society's complaint to the implementation of zoning policy was reported by JawaPos.com on July 27, 2019. It presented news of cheating on the zoning policy which was discovered by the Indonesian Ombudsman. Then it was also found that some students could not continue their studies. Thus, it was assessed that the zoning policy has not yet been feasible because the rules could not be applied by all schools in Indonesia.

TABLE I

COMPLAINTS FROM SOCIETY

\begin{tabular}{|c|c|c|c|}
\hline Source & Date & Actors & News \\
\hline $\begin{array}{l}\text { JawaPos.c } \\
\text { om }\end{array}$ & $\begin{array}{l}\text { July, } \\
5^{\text {th }}, \\
2019\end{array}$ & $\begin{array}{l}\text { North } \\
\text { Kaliman } \\
\text { tan } \\
\text { Society }\end{array}$ & $\begin{array}{l}\text { It was found that } 500 \text { students } \\
\text { cannot continue their study } \\
\text { because of the } \\
\text { implementation of the wrong } \\
\text { rules of zoning policy. }\end{array}$ \\
\hline $\begin{array}{l}\text { JawaPos.c } \\
\text { om }\end{array}$ & $\begin{array}{l}\text { July } \\
15^{\text {th }}, \\
2019\end{array}$ & $\begin{array}{l}\text { Ubaid } \\
\text { Mantraji }\end{array}$ & $\begin{array}{l}\text { In his opinion, zoning policy } \\
\text { is not appropriate because } \\
\text { there were quality gaps } \\
\text { among the schools in } \\
\text { Indonesia. }\end{array}$ \\
\hline $\begin{array}{l}\text { KRJOGJ } \\
\text { A.com }\end{array}$ & $\begin{array}{l}\text { July, } \\
15^{\text {th }}, \\
2019\end{array}$ & $\begin{array}{l}\text { Dharma } \\
\text { Setiawa } \\
\mathrm{n}\end{array}$ & $\begin{array}{l}\text { He asserted that the equal } \\
\text { distribution of Indonesian } \\
\text { education should not reduce } \\
\text { the standard of superior } \\
\text { schools. Students enrolment } \\
\text { should fulfill both } \\
\text { government and society's } \\
\text { needs. Moreover, the zoning } \\
\text { policy was narrowing down } \\
\text { the opportunities for students } \\
\text { from outside Yogyakarta to } \\
\text { study in Yogyakarta as an } \\
\text { educational center in } \\
\text { Indonesia. }\end{array}$ \\
\hline $\begin{array}{l}\text { KRJOGJ } \\
\text { A.com }\end{array}$ & $\begin{array}{l}\text { July } \\
15^{\text {th }}, \\
2019\end{array}$ & $\begin{array}{l}\text { Sutan } \\
\text { Adil } \\
\text { Hendra }\end{array}$ & $\begin{array}{l}\text { He asserted that the zoning } \\
\text { policy was detrimental to the } \\
\text { students who want to continue } \\
\text { their education at a particular } \\
\text { school. }\end{array}$ \\
\hline $\begin{array}{l}\text { JawaPos.c } \\
\text { om }\end{array}$ & $\begin{array}{l}\text { July } \\
27, \\
2019\end{array}$ & $\begin{array}{l}\text { Indonesi } \\
\text { an } \\
\text { Ombuds } \\
\text { man }\end{array}$ & $\begin{array}{l}\text { The zoning policy has not } \\
\text { been implemented well since } \\
\text { cheating was still found and } \\
\text { some students did not get a } \\
\text { school. }\end{array}$ \\
\hline
\end{tabular}

Furthermore, the newspapers reported some news about the impact of zoning policy implementation. The researchers summarized the news and presented it in Table II. 
TABLE II

ZONING POLICY PERCEIVED IMPACTS

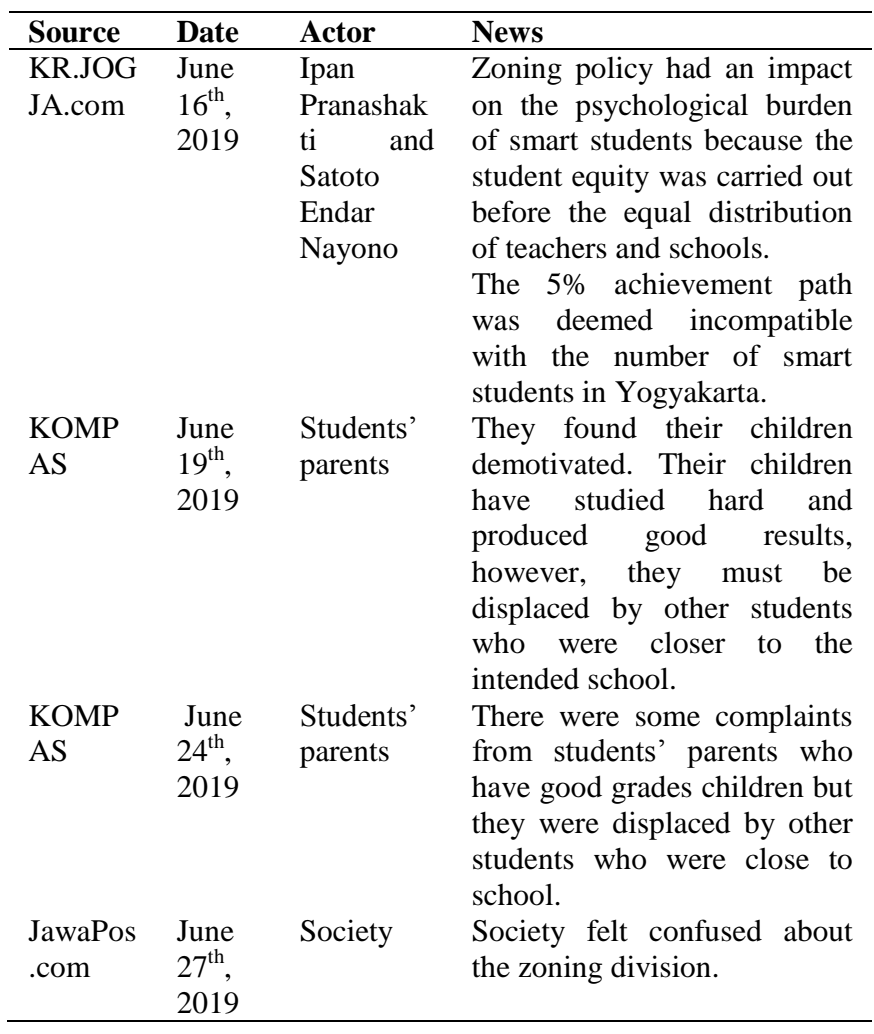

First, KRJOGJA.com on June 16, 2019, reported news by the members of Yogyakarta Society Forum, Ipan Pranashakti, and Satoto Endar Nayono. According to both members of the Yogyakarta Society Forum, zoning policy created a burden to smart students in Yogyakarta because the government failed to create fair educational systems across different schools. They also added that the government should consider the percentages of the achievement path. The 2019 policy mandates that only 5\% is merit-based. Meaning to say, the number of students with academically outperforming quality was very limited, i.e. $5 \%$ of the new students.

It was used to balance with the number of smart students in Yogyakarta. Furthermore, on June 19, 2019, KOMPAS reported complaints from parents about disappointment with the zoning policy implementation. They argued that the zoning policy had discouraged their children from learning. The zoning policy prioritized the closer house-to-school distance first and followed by students' scores.

Moreover, on June 24, 2019. KOMPAS also produced the same news, which was about parents who felt the displacement of their children by other students who were closer to school. Besides, JawaPos.com on June $27^{\text {th }}, 2019$ reported news by the voice of the community that society was confused by the area rules of zoning policy.

The three newspapers KRJOGJA.com, KOMPAS, and JawaPos.com also presented news containing responses and information from the government about the rules and benefits of the zoning policy. A summary of the government's responses was presented in Table III.

TABLE III

GOVERNMENT RESPONSES

\begin{tabular}{|c|c|c|c|}
\hline Source & Date & Actor & News \\
\hline \multirow{5}{*}{$\begin{array}{l}\text { KRJOG } \\
\text { JA.com }\end{array}$} & June & Muhadjir & Defending the \\
\hline & 23th & Effendy, & achievement paths have been \\
\hline & & Minister of & correct. \\
\hline & 2019 & Education & \\
\hline & & and $\mathrm{C}$ & $\begin{array}{l}\text { Announcing that the policy } \\
\text { has become a presidential } \\
\text { decree }\end{array}$ \\
\hline \multirow{2}{*}{$\begin{array}{l}\text { KOMP } \\
\text { AS }\end{array}$} & June & Muhadjir & Explaining the purpose and \\
\hline & $\begin{array}{l}24^{\text {th }} \\
2019\end{array}$ & Effendy & $\begin{array}{l}\text { importance of the zoning } \\
\text { policy }\end{array}$ \\
\hline \multirow{3}{*}{$\begin{array}{l}\text { KOMP } \\
\text { AS }\end{array}$} & June & Muhadjir & Responding \\
\hline & $24^{\text {th }}$, & Effendy & complaints about the \\
\hline & 2019 & & $\begin{array}{l}\text { implementation of the zoning } \\
\text { policy. }\end{array}$ \\
\hline
\end{tabular}

Confirming the local government's pivotal role in regulation enforcement.

$\begin{array}{lll}\text { KOMP } & \text { June } & \text { Muhadjir } \\ \text { AS } & 26^{\text {th }}, & \text { Effendy } \\ & 2019 & \\ & & \\ \text { KOMP } & \text { June } & \text { Teachers' } \\ \text { AS } & 26^{\text {th }}, & \text { voice } \\ & 2019 & \end{array}$

Reaffirming the function of zoning policy as well as for the development of education in Indonesia.

Expressing the unjust impacts, i.e. the equal distribution of students in the zoning policy would be beneficial for teachers to activate their agencies to create intelligent students.

$\begin{array}{lllll}\text { JawaPos } & \text { June } & \text { Rami } & & \text { Supporting the zoning policy } \\ \text {.com } & 29^{\text {th }}, & \text { Ramlan } & \text { for its } & \text { well-intended } \\ & 2019 & & \text { outcomes. }\end{array}$ Blaming parents for rejecting the policy.

$\begin{array}{lll}\text { KRJOG } & \text { July } & \text { Muhadjir } \\ \text { JA .com } & 1^{\text {st }}, & \text { Effendy } \\ & 2019 & \end{array}$

Explaining the revision of students' enrolment in 2019 which had focused on the area and student manipulation.

Mind-set shifts: students' parents to change their mind about favorite schools.

JawaPos July The Head of Claiming the implementation .com $5^{\text {th }}$, North was good.

2019 Kalimantan'

$s$ Office of Solutions for problems are Education always available.

and Culture

JawaPos July Indonesian Presenting the evaluation of .com $15^{\text {th }}$, Minister of students' enrolment in 2019 so 2019 Education that it can run better next year.

JawaPos July Surabaya Claiming that all schools are .com $16^{\text {th }}$, Mayor equal in quality. Every 2019 student has to be enthusiastic in learning wherever schools they study. 


\begin{tabular}{|c|c|c|c|}
\hline Source & Date & Actor & News \\
\hline KRJOG & July & Muhadjir & Affirming the function of the \\
\hline JA.com & $\begin{array}{l}21^{\mathrm{st}}, \\
2019\end{array}$ & Effendy & $\begin{array}{l}\text { zoning policy to solve } \\
\text { educational problems in } \\
\text { Indonesia. }\end{array}$ \\
\hline $\begin{array}{l}\text { JawaPos } \\
\text {.com }\end{array}$ & $\begin{array}{l}\text { July } \\
27^{\text {th }} \\
2019\end{array}$ & $\begin{array}{l}\text { Muhadjir } \\
\text { Effendy }\end{array}$ & $\begin{array}{l}\text { Ensuring that in the future the } \\
\text { zoning policy would be } \\
\text { strengthened by a Presidential } \\
\text { Regulation so that the goal of } \\
\text { zoning policy in the form of } \\
\text { equitable education could be } \\
\text { successful. }\end{array}$ \\
\hline
\end{tabular}

From three newspapers as the sources of this study, 12 reports were containing the positive responses of zoning policy implementation. The news came from the planners, implementers, and supporters of the zoning policy in Indonesia.

All three newspapers have raised news about the importance of the zoning policy that was designed and implemented in Indonesia to improve education in Indonesia. Besides, the newspaper also published news that strengthened the importance of zoning policy.

First, KRJOGJA.com on June 23, 2019, presented news that zoning policy had been submitted as a Presidential Regulation. Second, KOMPAS published June 24, 2019, reported that Mr. Muhadjir Effendy as the Indonesian Education Minister had ordered the Local Government to improve the quality of schools. Third, on June 26, 2019, KOMPAS drew the opinions of some teachers who supported the zoning policy. Followed by JawaPos.com on June 29, 2019 also published news from the Chairman of Teachers Association, Mr. Ramli who stressed the importance of zoning policy to improve the agency of teachers in Indonesia. Furthermore, JawaPos.com on July 5, 2019, published news about the solution for the North Kalimantan students who had not yet got a school. Then, Mr. Muhadjir Effendy through JawaPos.com on July 15, 2019, stated that he always revised the zoning policy regulations so that it would run better. Moreover, JawaPos.com added the Mayor of Surabaya's point of view about schools' condition concerning the zoning policy on July 16. She encouraged students through a statement that all schools are favorite schools. The last very strong news was presented by JawaPos.com on July 27 that zoning policy had been submitted as a Presidential Regulation so that it would get strong legal requirement.

\section{B. Discussion}

\section{The Issues were Addressed through the News Reports}

Empirical studies on news reports (e.g. Zhang, 2014; Hart, 2015) suggest that the language of news reports tends to endorse those in power, while remain to appear just to all society members. The news raised in the three online newspapers strongly suggests euphemistic reporting, to lessen the tensions among related parties in the field.

A case in point, three newspapers namely KRJOGJA.com, KOMPAS, and JawaPos.com as the sources of this discourse analysis study formulated both information from society and government concerning zoning policy implementation in a delicate balance. The JawaPos.com and KRJOGJA.com newspapers presented three news categories, namely the society complaints, the impact of the zoning policy, and the government's response. While the KOMPAS newspaper presented 2 types of news only, namely the impact of the zoning system and the government's response.

JawaPos.com and KRJOGJA.com compiled the news by describing the names of community leaders who took part in the zoning policy complaint, whereas KOMPAS took the viewpoint of students' parents and the Government only. Unfortunately, all newspapers did not show the news from students as the recipients and implementers of zoning policy.

The three newspapers as the sources of this study presented warm or negative situations in the implementation of the zoning policy. So the readers knew the sustainability of the zoning policy implementation that was not following its objectives. These news reports can also cause the level of worry in the community to arrange their children's education in the future.

Through KRJOGJA.com, KOMPAS, and JawaPos.com Mr. Muhadjir Effendy as Indonesia's Minister of Education has repeatedly emphasized the goals or vision of the zoning policy. The positive responses were beneficial to balance conditions in the community and make people aware of the importance of education improvement in Indonesia. Apart from that, presenting news about the purpose of the zoning policy can be useful to remind the public about the importance of the process of implementing the zoning policy. Every student in Indonesia must have the same rights and obligations in Education. The news packaging model that showed society's complaints, negative impacts, and positive responses from the government were useful to balance the news. Therefore, Indonesian people as readers and implementers of the zoning policy will have good consideration about their children's education.

2. The Agendas or Power were Contested in the Students' Enrolment Zoning Policy

Through discourse analysis using three newspapers as the sources, it was found that the packaging of news did not present the voice of the most influenced by the regulation itself. First, JawaPos.com and KRJOGJA.com presented the voices of community leaders in the complaint news category. Interestingly, KOMPAS did not raise the voice of community leaders and did not present the news society complaints. One of the most widely-read national newspaper, KOMPAS appears to take a soft side, avoiding a tricky situation by avoiding sensitive news reports that may cause the authority to lose face.

Policy framework in a democratic society requires a contesting space played by respective discourse community members. However, KOMPAS fails to embrace the different community members to be raised, such as the voice of community leaders. Community leaders' voice is arguably a significant contributor to allow the policy to be appropriately tested and contested to create wider subscriptions among the society members. In this discourse analysis study, it was 
found that KOMPAS never included the voices of community leaders so that the power of the news presented by KOMPAS did not have a large influence on zoning policy.

Furthermore, the three newspapers in this study did not present the voices of students who were recipients and implementers of the zoning policy. Indonesia has a very wide area so it also has many students as well. From the perspective of community representatives listed in the news summary above, the distribution of school quality was not evenly distributed so there were gaps between schools around Indonesia. In this case, students were the victims of the zoning policy implementation. So it is important to know the students' voice toward zoning policy implementation. As confirmed by Arsanto and Budiraharjo's (forthcoming) research about students' demotivation as the impact of zoning policy implementation that the students feel demotivated because of a classroom environment. The diversity of students is the most factor that creates demotivation.

\section{CONCLUSIONS}

This study was set to problematize the news reports on the zoning policy during its peak moment of the 2018 academic year. News reports gathered from three major online news agencies suggest that the news coverages were not evenly presented. The study yields that complaints from the society and responses from the authority appear to dominate the news reports. It is also evident that some news agencies seem to play safe, and avoid bringing forward those suffering most from the policy implementation.

In conclusion, this discourse analysis found that the three online news agencies fail to voice the marginalized groups, i.e. parents and students, as major recipients of the policy implementation. However, given the limited data sources (i.e. three online news agencies), further research, that encompasses more scope and duration, is recommended. Instead of investigating the news reports, it is also of great value to capture what happened to schools and students in the face of zoning policy implementation.

\section{REFERENCES}

Carina, J. (2019, June 24). Banyak keluhan soal PPDB sistem zonasi. KOMPAS.com. Retrieved on August 14, 2019, from https://yogyakarta.kompas.com/read/2019/06/24/19 413101/banyak-keluhan-soal-ppdb-sistem-zonasiini-pembelaan-mendikbud?page $=$ all

Cheek, J. (2004). At the margins? Discourse analysis and qualitative research. Qualitative health research, 14(8), 1140-1150.

Education and Culture Ministry (2018), Ministerial Policy on Grade School Students Enrolment (Education Ministry Policy No. 14).

Ginanjar, D. (2019a, June 29). Opini Wawancara Terkait $P P D B$. JawaPos.com. Retrieved on August 14, 2019 , from https://www.jawapos.com/opini/wawancara/29/06/2 019/terkait-ppdb-ramli-rahim-yang-ribut-adalahpara-orang-tua-egois/

Ginanjar, D. (2019b, July 16). Hari pertama dengan sistem Zonasi semua sekolah bisa jadi favorit. JawaPos.com. Retrieved on August 14, 2019, from https://www.jawapos.com/?s=Hari+Pertama+denga $\mathrm{n}+$ Sistem+Zonasi\%2C+Semua+Sekolah+Bisa+Jadi + Favorit

Hart, C. (2015). Viewpoint in linguistic discourse: Space and Evaluation in news reports of political protests. Critical Discourse Studies, 12(3), 238-260.

Hewitt, S. (2009). Discourse analysis and public policy research. Centre for rural economy discussion paper series, 24, 1-16.

Hutapea, E. (2019, June 26). Zonasi PPDB dinilai hilangkan sekolah favorit. KOMPAS.com. Retrieved on August 14, 2019 from https://edukasi.kompas.com/read/2019/06/26/20260 051/zonasi-ppdb-dinilai-hilangkan-sekolah-favoritapa-pendapat-guru?page $=$ all

Lova, C. (2019, June 19). PPDB sistem zonasi tak adil. KOMPAS.com. Retrieved on August 14, 2019, from

https://megapolitan.kompas.com/read/2019/06/19/1 9284581/orangtua-ppdb-sistem-zonasi-tak-adilanak-bisa-kalah-dengan-yang-nilainya?page=all

Mann, H. (1868). Life and works of Horace Mann (Vol. 3). Walker, Fuller and Company.

McCulloch, G. (1991). School zoning, equity and freedom: The case of New Zealand. Journal of Education Policy, 6(2), https://doi.org/10.1080/0268093910060204

Ramanathan, R., \& Hoon, T. B. (2015). Application of critical discourse analysis in media discourse studies. 3L: The Southeast Asian Journal of English Language Studies, 21(3), 57-68.

Sharp, L., \& Richardson, T. (2001). Reflections on Foucauldian discourse analysis in planning and environmental policy research. Journal of environmental policy and planning, 3(3), 193-209.

Sudjatmiko, T. (2019a, July 15). Zonasi PPDB jadi kebijakan sensitif. KRJOGJA.com. Retrieved on August 23, 2019, from https://krjogja.com/web/news/read/104524/Zonasi_ PPDB_jadi_Kebijakan_Sensitif

Sudjatmiko, T. (2019b, July 15). Zonasi PPDB lemahkan keIndonesian di DIY. KRJOGJA.com. Retrieved on August 23, 2019, from https://krjogja.com/web/news/read/104549/Zonasi_ PPDB_Lemahkan_Keindonesiaan_di_DIY

Suryowati, E. (2019a, June 27). Sistem zonasi bikin orang tua bingung. JawaPos.com. Retrieved on August 14, 2019 ,

from https://www.jawapos.com/nasional/27/06/2019/siste m-zonasi-bikin-orang-tua-bingung/

Suryowati, E. (2019b, July 5). Bakar ijazah, pelajar demo tolak sistem zonasi. JawaPos.com. Retrieved on August 14, 2019, from 
https://www.jawapos.com/jpg-

today/05/07/2019/bakar-ijazah-pelajar-demo-tolaksistem-zonasi/

Umasugi, R. A. (2019, June 24). Dalam PPDB sistem zonasi, nilai siswa tetap diperhitungkan. KOMPAS.com. Retrieved on August 14, 2019, from https://megapolitan.kompas.com/read/2019/06/24/1 4384081/dalam-ppdb-sistem-zonasi-nilai-siswatetap-diperhitungkan

Virdhani, M. (2019, July 27). Evaluasi mendikbud dan Ombudsman soal sistem zonasi PPDB. JawaPos.com. Retrieved on August 14, 2019, from https://www.jawapos.com/nasional/pendidikan/27/0 7/2019/evaluasi-mendikbud-dan-ombudsman-soalsistem-zonasi-ppdb-lewat-perpres/

Widiyanto, D. (2019a, June 16). Revisi Juknis PPDB SMA, SMK. KRJOGJA.com. Retrieved on August 23, 2019, from https://krjogja.com/web/news/read/102049/Revisi_J uknis_PPDB_SMA_SMK_Beban_Sistem_Zonasi_ PPDB_Ditimpakan_Siswa

Widiyanto, D. (2019b, June 23). Perpres soal sistem Zonasi PPDB bakal diterbitkan. KRJOGJA.com. Retrieved on August 23, 2019, from https://krjogja.com/web/news/read/102620/Perpres_ Soal_Sistem_Zonasi_PPDB_Bakal_Diterbitkan. 